\title{
International Productivity Differences and the Roles of Domestic Investment, FDI and Trade
}

\author{
GOURANGA G. DAS*, HIRANYA K. NATH** \\ \& HALIS MURAT YILDIZ ${ }^{\dagger}$
}

\author{
* Department of Economics and Business, Hanyang University, Kyunggi-Do, South Korea, \\ ** Department of Economics and International Business, Sam Houston State University, Texas, \\ USA, ${ }^{\dagger}$ Department of Economics, Ryerson University, Toronto, Canada
}

(Received 1 November 2006; final version received 12 June 2008)

\begin{abstract}
This paper calculates Theil's entropy index to measure the extent of productivity differences across 92 countries for the period from 1970 to 2003 . While there is evidence of increasing differences in productivity across these countries, we observe different patterns when we group the countries by income levels. These differences seem to be decreasing among middle income developing and developed countries, whereas they seem to be widening among low and high income developing countries. The results of our multivariate time series analysis also suggest that FDI increases productivity differences among low and high income developing countries, whereas GDI reduces these differences among low income countries in the long-run. Granger causality test results indicate that while an increase in GDI leads to a decline in growth of trade, a higher growth of trade appears to be important for attracting FDI to middle income countries. Furthermore, a reduction in productivity differences and a higher FDI growth lead to higher growth of trade in developed countries.
\end{abstract}

KEY Words: Productivity differences, Theil's index, entropy, domestic investment, foreign direct investment, trade openness, cointegration, Granger causality

JEL CLASSIFICATION: F02, F21, F43

Correspondence Address: Halis Murat Yildiz, Department of Economics, Ryerson University, Toronto, Canada.Email: hyildiz@ryerson.ca 


\section{Introduction}

One of the basic principles we teach in an introductory level economics class is that a country's standard of living depends on its productivity, and the large variation in living standards around the world is explained by differences in productivity: countries with high productivity have high standards of living and vice versa. ${ }^{1}$ What is the extent of these differences? Is it possible to have a single measure of productivity differences across countries? How has this disparity evolved over time? The primary objective of this study is to measure the extent of differences in productivity across countries, and to track its changes over time. A secondary objective is to examine if accumulation of physical capital through domestic investment and foreign direct investment (FDI), and trade have any systematic effects on inter-country differences in productivity. It is widely recognized in the growth literature that capital accumulation and technological progress are very important for productivity growth, and to that effect domestic investment and FDI assume important roles. FDI not only augments domestic capital stock but also acts as a conduit for technology transfer from the source countries to the recipient countries. ${ }^{2}$ Furthermore, countries that have more liberal trade environment can achieve higher productivity through efficient allocation of resources.

Although there have been previous attempts (for example Ram, 1989; Bhatta, 2002) to measure differences (inequality) in per capita income across countries, to the best of our knowledge, there has not been any study that measures intercountry differences in productivity. As for the effects of domestic or foreign investment and trade, the related empirical literature mainly focuses on the effects of FDI and domestic investment on growth under different trade environments. For example, using cross-country regression analysis, Balasubramanyam et al. (1996) find that the growth-enhancing effects of FDI are stronger in countries with more liberal trade regimes. Based on time series and panel data evidence for a sample of OECD and non-OECD countries, de Mello (1999) concludes that FDI increases productivity in recipient countries, and it is often a catalyst for domestic investment and technological progress. Using the panel causality tests technique, Nair-Reichert \& Weinhold (2001) find no uniformity among countries in the effects of FDI on growth but find evidence of higher efficacy of FDI for enhancing growth in more open economies. Basu et al. (2003) use a panel cointegration framework to demonstrate that there exists a long-run bi-directional causality between growth and FDI for more open economies and uni-directional causality that runs from growth to FDI for relatively closed economies.

While the above studies examine the causal relationship between FDI and growth in different trade environments, Borensztein et al. (1998) investigate the growth enhancing role of FDI in the context of purely domestic environments in the recipient countries. They find that FDI contributes relatively more to growth than does domestic investment when sufficient absorptive capability in the form of a minimum stock of human capital is available in the host country. Choe (2003) employs a panel VAR model framework to examine the Granger-causality

\footnotetext{
${ }^{1}$ For example, see Mankiw (2004, chapter 1).

${ }^{2}$ In the literature, the role of FDI in transferring technology has received much attention and spurred intense debate. For a survey, see Saggi (2002).
} 
between growth, FDI flows and gross domestic investment (GDI) for 80 countries over 1971-95. The findings are, however, inconclusive about the direction of causality especially between FDI and growth, although for GDI it seems to run from growth to GDI.

This paper aims to make two contributions to the literature. First, it presents a single measure of productivity differences across countries and studies its evolution over the period 1970-2003. In particular, it uses Theil's entropy index to measure spatial differences in productivity across 92 countries. Results indicate that, although the differences in productivity have increased for the full sample of countries, different patterns of time series behavior arise when we categorize the countries by different income levels. Second, this study also examines if GDI, FDI and trade have any systematic effects on behavior of the productivity difference measure in the long-run as well as in the short-run. The results of our multivariate time series analysis suggest that FDI increases productivity differences among low and high income developing countries, while GDI reduces these differences among low income countries in the long-run. Furthermore, Granger causality test results suggest that while an increase in GDI leads to a decrease in the growth of trade, a higher growth of trade appears to be important for attracting FDI to middle income countries. In addition, a reduction in productivity differences and a higher level of FDI growth are important for growth of trade in developed countries.

The rest of the paper is organized as follows. Section 2 discusses Theil's entropy measure that we use for studying differences in productivity across countries. In section 3, we discuss the data and variables of interest. Section 4 presents the results, their analysis, and the discussion. Section 5 includes our concluding remarks.

\section{Measuring Differences in Productivity}

In order to measure the extent of differences in productivity across countries, we use a measure of spatial inequality based on Theil's entropy measure of income inequality. Originally developed in statistical thermodynamics, entropy is an information theoretic measure that was first applied to the analysis of income distribution by Theil (1967), and has been used to measure inter-country/regional income disparity in several previous studies (e.g. Ram, 1989; Cuadrado et al., 1993; and Das \& Barua, 1996). In particular, we treat each country as one unit and calculate a labor-share weighted index of inter-country productivity differences (Theil's index, hereafter) as follows:

$$
I_{t}=\sum_{i=1}^{n} l_{i, t} \ln \left(\frac{l_{i, t}}{y_{i, t}}\right)
$$

where $l_{i, t}$ and $y_{i, t}$ are, respectively, labor share and GDP share of country $i$ in period $t$. That is:

$$
l_{i, t}=\frac{L_{i, t}}{L_{t}} \quad \text { and } \quad y_{i, t}=\frac{Y_{i, t}}{Y_{t}}
$$

where $L_{i, t}$ is the number of workers and $Y_{i, t}$ is the real GDP in country $i$ in period $t ; L_{t}$ and $Y_{t}$ are respectively the total number of workers in all countries and the 
aggregate real GDP; and $n$ is the number of countries in the sample. In this form, $I_{t}$ measures inequality by aggregating the ratios between labor share and real GDP share across countries. Note that a country with relatively high labor productivity has a ratio lower than unity and a country with relatively low productivity has a ratio greater than unity. The real GDP shares and labor shares can be regarded as prior and posterior probabilities. The value of $I_{t}$ lies between 0 , which indicates complete equality, and $n-1$, which indicates extreme inequality.

To facilitate an alternative explanation we can rewrite the above equation as follows:

$$
I_{t}=\sum_{i=1}^{n} l_{i, t} \ln \frac{\left(Y_{t} / L_{t}\right)}{\left(Y_{i, t} / L_{i, t}\right)}
$$

A closer examination of this representation reveals that it is a weighted average of the deviations of labor productivity in each country from the average labor productivity of all countries in the sample.

There are several advantages of this measure over other conventional measures of inequality. First, it is independent of the size variations among countries. Second, unlike other measures, such as coefficient of variations, the entropy captures all moments of the distribution. Third, although it is an average index, it provides information on the relative position of a country in the sample as described in terms of the ratios (see Das \& Barua, 1996).

\section{Data and Variables}

\subsection{Data Sources}

The data used for this study are obtained from several sources. They are: [1] the United Nations Statistical Databases available online at the UN website; [2] the Penn World Table (PWT 6.1), compiled and made available online by the Center for International Comparisons (CIC) at the University of Pennsylvania; [3] the International Labor Organization (ILO) LABORSTAT (an online database of labor statistics); and [4] the FDI database available online at the United Nations Conference on Trade and Development (UNCTAD) website.

We obtain data on real GDP, gross fixed investment, and exports and imports (all at 1990 US constant dollar prices) for 92 countries for a period from 1970 to 2003 from source [1]. ${ }^{3}$ The choice of the sample period and the number of countries is dictated by the availability of data. ${ }^{4}$ The countries for which data are not available for a reasonable length of time have been excluded from the sample. Data on the number of economically active workers are obtained from sources [2] and [3]. The Penn World Table uses ILO data on economically active population to calculate GDP per worker. Since ILO does not provide data for all years for many countries, the PWT interpolates for missing years and we use those interpolated data. However, the PWT data set extends only up to 2000 and,

\footnotetext{
${ }^{3}$ Ideally, we would like to use PPP real GDP (in international dollars) but the Penn Tables provide data only up to 2000. Moreover, the FDI data are available in US dollars only.

${ }^{4}$ Countries included in our sample are listed in Appendix B.
} 
therefore, we use additional data from ILO database for 2001 to 2003 and use a linear interpolation/extrapolation method wherever necessary.

We obtain data on net FDI inflows from source [4]. ${ }^{5}$ UNCTAD reports the FDI flows in current US dollars. They are converted in to 1990 US dollars by using an implicit deflator for gross fixed investment calculated using data obtained from source [1]. We subtract foreign direct investment from gross fixed investment to obtain the domestic component - which we would call gross domestic investment or GDI - in each country for the sample period.

\subsection{Variables}

\subsubsection{Productivity Measure}

Since this study is about productivity differences across countries, the first question is: how do we measure productivity? Although productivity is defined as the amount of goods and services produced from each hour of a worker's time, a dearth of reliable data on hours is a formidable problem. As an alternative, we use real GDP per worker as the productivity variable. Following Penn World Table Technical Appendix, we calculate real GDP per worker for each country by dividing real GDP by economically active population. Note that this definition of productivity is embedded in Theil's index.

\subsubsection{Aggregate Measures of FDI, GDI and Trade}

Since one of the objectives of the current study is to examine the effects of domestic and foreign investment and of trade openness on the evolution of productivity differences over time, we would like to introduce some aggregate measures of these variables. To that end, we construct three weighted indices for each year. The GDI index $\left(G D I X_{t}\right)$ reflects accumulation of domestic capital per worker across countries in a given year. Thus:

$$
G D I X_{t}=\sum_{i=1}^{n} \frac{G D I_{i, t}}{L_{i, t}} \times \frac{L_{i, t}}{L_{t}}
$$

where $G D I_{i, t}$ is the gross domestic investment in country $i$ in period $t . L_{i, t}$ and $L_{t}$ are as described before. Thus, we use country $i$ 's labor share in the aggregate as the weight for calculating the GDI weighted index. ${ }^{6}$ Similarly, the FDI index

\footnotetext{
${ }^{5} \mathrm{FDI}$ inflows in the recipient economy 'comprise capital provided (either directly or through other related enterprises) by a foreign direct investor to an enterprise resident in the economy.' 'FDI flows are recorded on a net basis (capital account credits less debits between direct investors and their foreign affiliates) in a particular year.' (See UNCTAD: Foreign Direct Investment database, Sources and Notes.)

${ }^{6}$ In a sensitivity exercise we calculate these indices by weighing GDI per worker, FDI per worker and trade per worker in country $i$ with the country's GDP share in the sample. Although the magnitudes of these indices under this alternative weighing system differ, the qualitative results of our analysis of the relationship do not change significantly. Due to both saving space and a lack of significant differences, we do not report the results in the paper. The results can however be obtained from the authors.
} 
$\left(F D I X_{t}\right)$ reflects the availability of FDI per worker in the sample countries in a given year:

$$
\text { FDIX }_{t}=\sum_{i=1}^{n} \frac{F D I_{i, t}}{L_{i, t}} \times \frac{L_{i, t}}{L_{t}}
$$

where $F D I_{i, t}$ is the inflow of foreign direct investment to country $i$ in period $t$.

In addition, we calculate a weighted index of total trade per worker for each year as follows:

$$
\operatorname{TRADE}_{t}=\sum_{i=1}^{n} \frac{T R A D E_{i, t}}{L_{i, t}} \times \frac{L_{i, t}}{L_{t}}
$$

where $T R A D E_{i, t}$ is obtained as the sum of exports and imports (at constant prices in country $i$ in period $t$ ).

\section{Empirical Results}

In this section, we first present our results on the measurement of productivity differences across countries. We are also interested in examining how these differences have changed over time. We examine productivity differences for the full sample that includes both developed and developing countries, as well as for four different income groups of countries as classified by UNCTAD. This classification scheme, based on per capita GDP divides these countries into low income developing countries, middle income developing countries, high income developing countries and developed countries.

\subsection{Productivity Differences Across Countries}

To get a snapshot view of the distribution of productivity, we first plot in Figure 1 the maximum, the minimum and the average of productivity for each group of countries for each year during the sample period. For the full sample, the average productivity increased slightly. For low income countries the average productivity declined slightly whereas for middle income developing countries there has been a slight increase. However, average productivity shows clear signs of increase in high income developing countries and developed countries. While the range between maximum and minimum has increased for the full sample, high income developing and developed countries, it declined for low income developing countries and did not show any clear pattern for middle income developing countries. However, these graphs could be deceptive about productivity differences as the extreme values could be just outliers and therefore may not be very revealing.

We plot Theil's index for the full sample as well as for four income groups of countries, and present them in Figure 2. For the full sample it is difficult to discern a general pattern in the year-to-year variation in productivity differences. We observe sharp upward spikes in 1973, 1979, 1990-1992 and 2001. Similarly there were sharp declines in 1975, 1982-1983 and 1996. Fitting of a linear trend line suggests that inequality increased significantly during this period (see Table 1). Among the low income developing countries, productivity differences increased 
Full Sample: 92 Countries
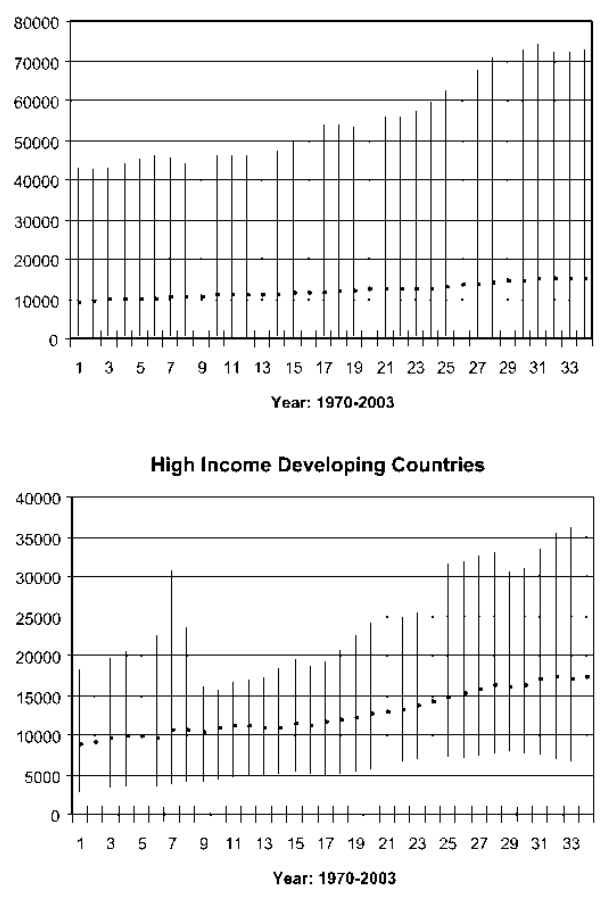

Low Income Developing Countries

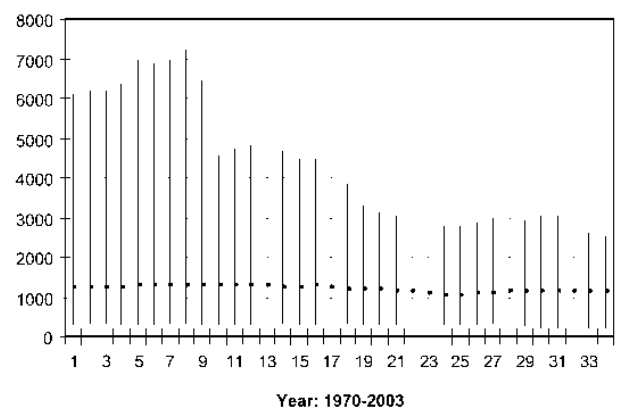

Middle Income Developing Countries

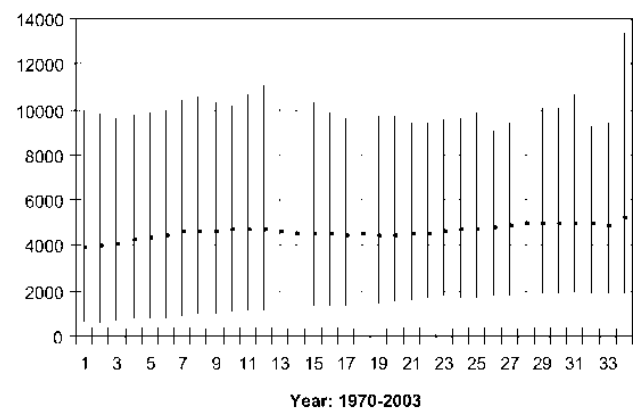

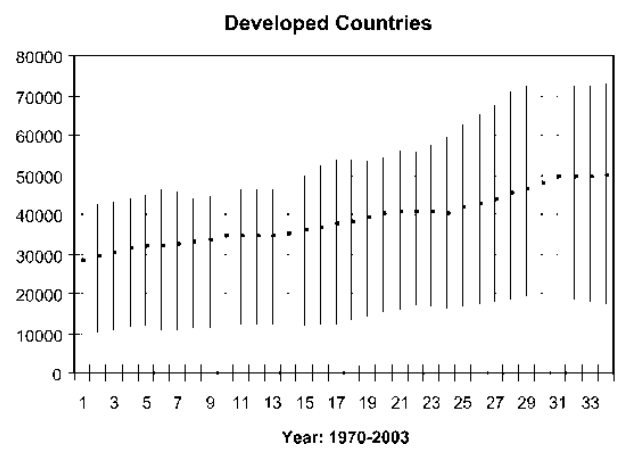

Figure 1. The maximum, minimum and the average of productivity in 1990 US dollar.

until 1974, slightly declined through 1990 and steadily increased thereafter. For middle income developing countries we observe a smoothly declining trend until the mid-1990s and a slight increase over the last few years. Productivity differences among high income developing countries declined until the mid-1980s and then increased steadily since then. Among developed countries, there has been a steady decline with a slight turning around in the late 1990s.

In order to further examine the long-run behavior of productivity differences, we fit a linear time trend to the inequality measure and report the trend coefficients in Table 1. Theil's measure exhibits significant negative trends for middle income and developed countries, and significant positive trends for the full sample, low 

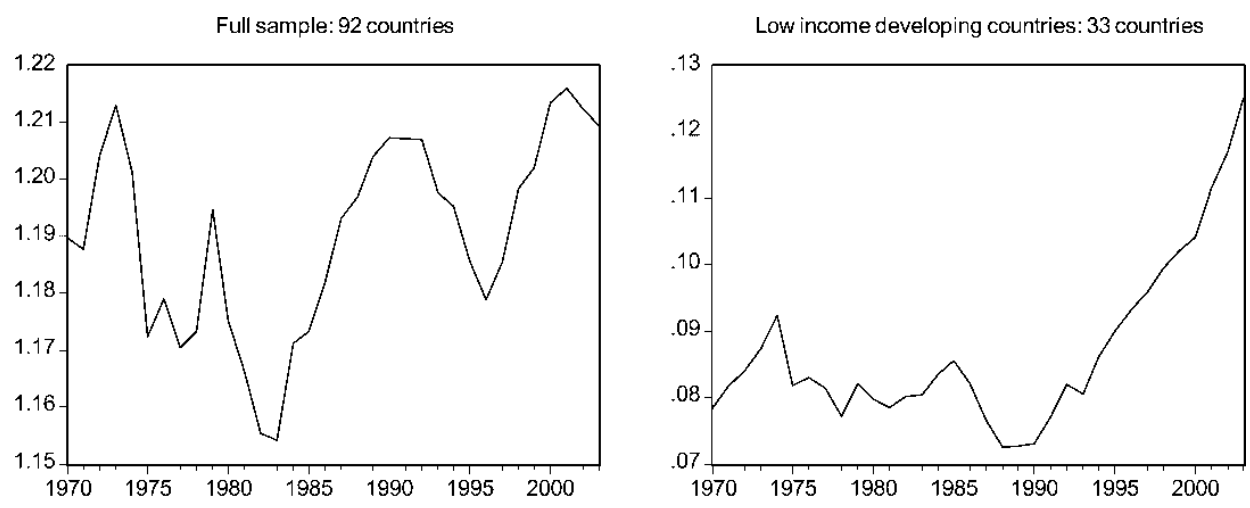

Middle income developing countries: 26 countries

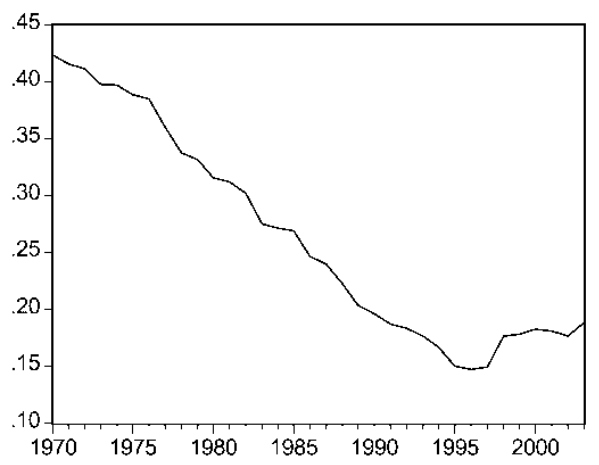

High income developing countries: 13 countries
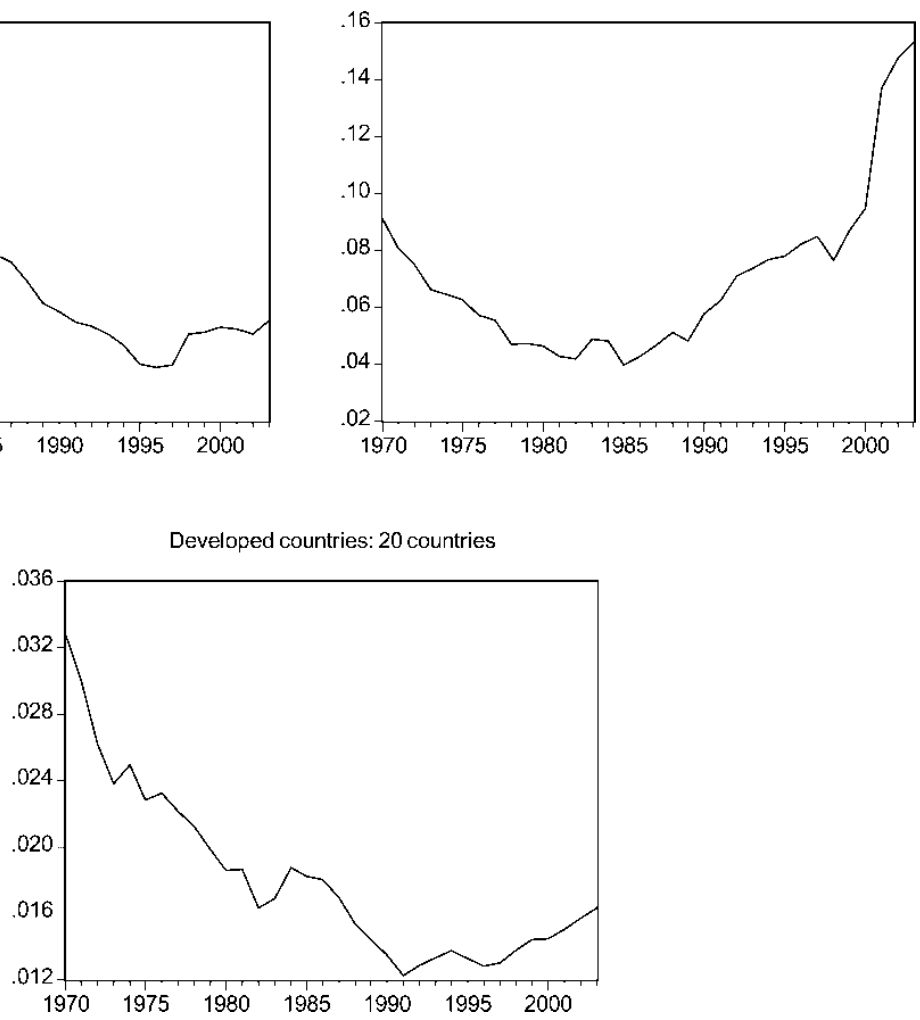

Figure 2. Productivity differences across countries: Theil's inequality measures 1970-2003.

and high income developing countries. The magnitudes of Theil's measure for the developed countries are the lowest and closest to zero, indicating relatively smaller differences in productivity among developed countries. These magnitudes are relatively larger for middle income developing countries. It is not surprising that these inequality measures are the largest in magnitude for the full sample. 
Table 1. Linear trend coefficients for Theil's inequality measures

\begin{tabular}{lc}
\hline Groups & Estimated trend coefficient \\
\hline All countries & $0.001(2.63)$ \\
Low income developing countries & $0.0001(4.54)$ \\
Middle income developing countries & $-0.009(-17.37)$ \\
High income developing countries & $0.002(3.83)$ \\
Developed countries & $-0.0004(-9.12)$ \\
\hline
\end{tabular}

Note: $t$-statistics are in parentheses.

Table 2. Correlation between Theil's measure and spatial Gini coefficient of productivity differences

\begin{tabular}{lc}
\hline Groups & Correlation coefficient \\
\hline All countries & $0.67(5.11)$ \\
Low income developing countries & $0.73(6.04)$ \\
Middle income developing countries & $0.995(56.36)$ \\
High income developing countries & $0.99(39.70)$ \\
Developed countries & $0.98(27.86)$ \\
\hline
\end{tabular}

Note: $t$-statistics are in parentheses.

For comparison, we also calculate a Spatial Gini Coefficient (GS). A similar measure for inequality of per capita income across countries has been used, most notably by Bhatta (2002). Appendix A includes a description of this measure. In Table 2, we present the correlation coefficients of Theil's index with the Gini measure. As we can see from the table, the Gini index is highly positively correlated with Theil's index for all groups. This exercise suggests that Theil's entropy measure captures very well the inequality in productivity across countries.

We further examine the stochastic trend properties of Theil's index. We conduct the Augmented Dickey-Fuller (ADF) test to find out the order of integration for each of the four series. First, we conduct the test in levels and then in first differences for the full sample as well as for various groups of countries. ${ }^{7}$ For each series we start with the most flexible specification of the test equation that includes an intercept and a trend:

$$
\Delta I_{t}=\alpha_{o}+\alpha_{1} t+\gamma I_{t-1}+\sum_{i=1}^{p} \beta_{i} \Delta I_{t-i}+\varepsilon_{t}
$$

where $\alpha_{0}$ represents the intercept term, $t$ is the deterministic time trend, $\Delta I_{t-i}$ is the augmented term, $p$ is the appropriate lag length of the augmented terms and $\varepsilon$ is the white noise error term. The ADF test is essentially the test of significance of the coefficient $\gamma$ in the above equation. In order to select the lag length $p$, we start with a maximum lag of four and pare it down to the appropriate lag by looking

\footnotetext{
${ }^{7}$ If we find evidence of a unit root in first difference of a series we further conduct an ADF test on the second difference of that series.
} 
Table 3. Augmented Dickey-Fuller test results for Theil's measure (sample period: 1970-2003)

\begin{tabular}{|c|c|c|c|c|c|}
\hline Statistics & $\begin{array}{l}\text { Full } \\
\text { sample }\end{array}$ & $\begin{array}{l}\text { Low income } \\
\text { developing } \\
\text { countries }\end{array}$ & $\begin{array}{l}\text { Middle income } \\
\text { developing } \\
\text { countries }\end{array}$ & $\begin{array}{l}\text { High income } \\
\text { developing } \\
\text { countries }\end{array}$ & $\begin{array}{c}\text { Developed } \\
\text { countries }\end{array}$ \\
\hline \multicolumn{6}{|l|}{ Panel A: In levels } \\
\hline ADF test statistics & -0.30 & 2.29 & -4.60 & -0.40 & -4.66 \\
\hline $\begin{array}{l}\text { Lag length of the augmented } \\
\text { terms }\end{array}$ & 0 & 0 & 0 & 0 & 0 \\
\hline $\begin{array}{l}\text { Is a time trend included in } \\
\text { the test equation? }\end{array}$ & no & no & no & yes & no \\
\hline $\begin{array}{l}\text { Is an intercept term included } \\
\text { in the test equation? }\end{array}$ & no & no & no & yes & yes \\
\hline $\begin{array}{l}\text { Dickey-Fuller 5\% critical } \\
\text { value }\end{array}$ & -1.95 & -1.95 & -1.95 & -3.55 & -2.95 \\
\hline $\begin{array}{l}\text { MacKinnon approximate } \\
\text { p-value }\end{array}$ & 0.77 & 0.99 & 0.00 & 0.98 & 0.00 \\
\hline $\begin{array}{l}\text { Number of obs. used in the } \\
\text { test equation }\end{array}$ & 33 & 33 & 33 & 33 & 33 \\
\hline $\begin{array}{l}\text { Panel B: In first differences } \\
\text { ADF test statistics }\end{array}$ & -4.84 & -5.09 & & -5.46 & \\
\hline $\begin{array}{l}\text { Lag length of the augmented } \\
\text { terms }\end{array}$ & 0 & 0 & & 0 & \\
\hline $\begin{array}{l}\text { Is a time trend included in } \\
\text { the test equation? }\end{array}$ & no & yes & & yes & \\
\hline $\begin{array}{l}\text { Is an intercept term included } \\
\text { in the test equation? }\end{array}$ & no & yes & & yes & \\
\hline $\begin{array}{l}\text { Dickey-Fuller } 5 \% \text { critical } \\
\text { value }\end{array}$ & -1.95 & -3.56 & & -3.56 & \\
\hline $\begin{array}{l}\text { MacKinnon approximate } \\
\text { p-value }\end{array}$ & 0.00 & 0.00 & & 0.00 & \\
\hline $\begin{array}{l}\text { Number of obs. used in the } \\
\text { test equation }\end{array}$ & 32 & 32 & & 32 & \\
\hline
\end{tabular}

Note: To select the lag length of the augmented terms in the test equation, we start with a maximum lag length of four and pare it down by looking at the Schwartz Information Criterion (SIC).

at the Schwartz Information Criterion (SIC). ${ }^{8}$ If we do not find the intercept and trend - both or one of them - to be statistically significant at $10 \%$ significance level, we drop the insignificant term(s) and re-estimate the test statistics. The results of these ADF tests are reported in Table 3. In Panel A, we report the ADF test results for the variable in level and in Panel B we report them in first difference. As we can see from Table 3, for the full sample, low income and high income developing countries' Theil's index is an integrated process of order one

${ }^{8}$ There is no general rule as to how one chooses the maximum lag length to start with. Enders (2004, 192) suggests 'to start with a relatively long lag length...'. Some researchers use the following rule of thumb: start with a maximum lag length equal to the cube root of the number of observation which is $3.24(=\sqrt[3]{34})$ in our case. 
(i.e. $I(1)) .{ }^{9}$ For middle income developing and developed countries, we find that the productivity difference measure is stationary.

The augmented Dickey-Fuller test procedure is often criticized for the assumptions of statistical independence and constant variance of the underlying distribution of the errors, and for low power in a small sample. Phillips \& Perron (1988) develop a non-parametric test procedure that allows fairly mild assumptions regarding the distribution of the errors. We therefore use the Phillips-Perron methodology as a cross-check on the results suggested by the ADF tests about the orders of integration of the variables of interest. We do not find any conflicting results from this alternative test procedure.

\subsection{Roles of Domestic Investment, FDI and Trade}

The growth literature places utmost importance on capital accumulation and technology for determining productivity. While domestic investment is important for augmenting the stock of physical capital, FDI not only contributes to capital accumulation but also acts as a conduit for technology transfer. Furthermore, free trade enhances productivity through more efficient allocation of resources.

Table 4 presents some stylized facts about GDI, FDI and trade in 92 countries around the world. Panel A gives an idea about the relative positions of four groups of countries with regards to investment and trade. During the period 1970-2003, on average, only about $3 \%$ of total domestic investment took place in low income developing countries. The shares of middle income and high income developing countries were less than $10 \%$ each, whereas the 20 developed countries account for about $83 \%$ of total gross domestic investment. The share of FDI in low income developing countries is slightly above $2 \%$, in middle income countries about $8 \%$ and in high income countries about $13 \%$. The developed countries take the lion's share with about $77 \%$. The total volume of trade has a similar share distribution among these four groups. While low income countries account for slightly above $3 \%$, the developed countries account for about $79 \%$.

In panel B, we document the changes in per worker figures for each of these three variables at decennial intervals. Per worker GDI for the entire sample increased by about $37 \%$ between 1970 and 2003. While low income developing countries and developed countries witnessed steady growth, middle income countries experienced a slowdown in the 1980s, and so did high income countries in both the 1980s and 1990s. FDI in general has declined at the beginning of the twenty-first century. While all four groups of countries experienced growth in per worker FDI inflows during the three decades ending in 2000, in high income countries it increased by more than 20 times and in developed countries it rose by about 18 times. The growth in trade per worker has been the highest among the high income developing countries followed by developed countries, with low and middle income countries trailing far behind.

Before we investigate how domestic and foreign direct investment and trade across these countries have contributed to productivity differences around the

${ }^{9}$ As one can see from MacKinnon's approximate $p$-values, the results are based on conventional $5 \%$ significance level (a $p$-value of 0.05 or less). 
Table 4. Share and growth of domestic and foreign investment and trade

\begin{tabular}{|c|c|c|c|c|c|}
\hline Year & Full sample & $\begin{array}{c}\text { Low income } \\
\text { developing } \\
\text { countries }\end{array}$ & $\begin{array}{c}\text { Middle income } \\
\text { developing } \\
\text { countries }\end{array}$ & $\begin{array}{l}\text { High income } \\
\text { developing } \\
\text { countries }\end{array}$ & $\begin{array}{c}\text { Developed } \\
\text { countries }\end{array}$ \\
\hline \multicolumn{6}{|c|}{ Panel A: Percentage share in total (1970-2003 average) } \\
\hline Gross domestic investment & 100 & 2.99 & 6.80 & 7.22 & 82.99 \\
\hline Foreign direct investment & 100 & 2.25 & 7.99 & 12.53 & 77.23 \\
\hline Trade & 100 & 3.27 & 9.67 & 8.20 & 78.74 \\
\hline \multicolumn{6}{|c|}{$\begin{array}{l}\text { Panel B: Trends over time } \\
\text { Gross domestic investment per worker }\end{array}$} \\
\hline 1970 & 2333.69 & 166.78 & 615.18 & 1634.88 & 6282.93 \\
\hline 1980 & 2698.67 & 173.71 & 994.74 & 2739.31 & 7233.20 \\
\hline 1990 & 2947.40 & 194.20 & 893.62 & 2524.41 & 9116.56 \\
\hline 2000 & 2884.46 & 250.64 & 944.37 & 2477.61 & 9627.36 \\
\hline 2003 & 3190.99 & 264.61 & 920.61 & 2454.70 & 11401.00 \\
\hline$\%$ growth rate $(1970-2003)$ & 36.74 & 58.66 & 49.65 & 50.15 & 81.46 \\
\hline \multicolumn{6}{|c|}{ Foreign direct investment per worker } \\
\hline 1970 & 45.06 & -13.74 & 30.14 & 51.46 & 127.58 \\
\hline 1980 & 72.55 & 1.91 & 23.26 & 112.61 & 190.13 \\
\hline 1990 & 141.66 & 3.11 & 38.69 & 155.44 & 441.43 \\
\hline 2000 & 657.79 & 19.33 & 66.98 & 1039.57 & 2246.69 \\
\hline 2003 & 207.49 & 40.51 & 61.63 & 344.33 & 620.18 \\
\hline$\%$ growth rate $(1970-2000)$ & 1359.81 & 458.67 & 122.23 & 1920.15 & 1661.00 \\
\hline \multicolumn{6}{|l|}{ Total trade per worker } \\
\hline 1970 & 2495.20 & 243.83 & 1282.15 & 1375.25 & 6351.83 \\
\hline 1980 & 3536.92 & 314.04 & 1768.71 & 2783.18 & 9270.93 \\
\hline 1990 & 4737.28 & 279.42 & 1994.63 & 5165.89 & 13942.5 \\
\hline 2000 & 8066.29 & 567.03 & 3360.79 & 12047.11 & 24869.13 \\
\hline 2003 & 8147.16 & 633.51 & 3252.55 & 10228.67 & 25281.08 \\
\hline$\%$ growth rate $(1970-2003)$ & 226.51 & 159.82 & 153.68 & 643.77 & 298.01 \\
\hline
\end{tabular}

world, we first need to examine the stochastic trend properties of each of the three series: GDIX, FDIX and TRADE so that we can use an appropriate technique for multivariate analysis. The results are reported in Table 5. Note that except for the middle income developing countries, all three series are unit root processes. ${ }^{10}$ GDIX and TRADE are $I(1)$ and FDIX is $I(0)$ for middle income developing countries.

Now that we know the univariate time series properties of the individual series we may turn to multivariate analysis in order to get further insights into the relationships among these variables.

\subsubsection{Cointegration Test}

The examination of any relationship between non-stationary variables would involve testing for cointegration, in particular if they are integrated of the same order. ${ }^{11}$ The ADF test and the Phillips-Perron test results suggest that I, GDIX,

\footnotetext{
${ }^{10}$ GDIX for the full sample is $I(0)$ according to ADF test but $I(1)$ according to the Phillips-Perron test.

${ }^{11}$ Cointegration refers to a long-run equilibrium relationship. 'In Engle and Granger's use of the term, the equilibrium relationship may be causal, behavioral, or simply a reduced-form relationship among similarly trending variables' (see Enders, 2004, 322).
} 
Table 5. Augmented Dickey-Fuller test results for foreign direct investment aggregate index, domestic investment aggregate index and trade openness index

\begin{tabular}{lccc}
\hline Groups of countries & $\begin{array}{c}\text { Natural log of } \\
\text { GDI index (GDIX) }\end{array}$ & $\begin{array}{c}\text { Natural log of FDI } \\
\text { index (FDIX) }\end{array}$ & $\begin{array}{c}\text { Natural log of } \\
\text { trade openness } \\
\text { index (TRADE) }\end{array}$ \\
\hline All countries & $\mathrm{I}(0) *$ & $\mathrm{I}(1)$ & $\mathrm{I}(1)$ \\
Low income developing countries & $\mathrm{I}(1)$ & $\mathrm{I}(1)$ & $\mathrm{I}(1)$ \\
Middle income developing countries & $\mathrm{I}(0)$ & $\mathrm{I}(1)$ & $\mathrm{I}(1)$ \\
High income developing countries & $\mathrm{I}(1)$ & $\mathrm{I}(1)$ & $\mathrm{I}(1)$ \\
Developed countries & $\mathrm{I}(1)$ & $\mathrm{I}(1)$ & $\mathrm{I}(1)$ \\
\hline
\end{tabular}

Note: * indicates that while the ADF test suggests that the series is a $I(0)$ process, the Perron-Phillips test suggests that it is an $I(1)$ process.

FDIX and TRADE are all integrated of same order (i.e. $I(1))$ for the full sample, low income developing, and high income developing countries. Therefore, we conduct Johansen's Cointegration Test for these three groups of countries. ${ }^{12}$ Note that Johansen's test procedure involves estimation of the following model:

$$
\Delta x_{t}=\sum_{i=1}^{p-1} \pi_{i} \Delta x_{t-i}+\pi x_{t-p}+\varepsilon_{t}
$$

where $x_{t}=\left(I_{t}, F D I X_{t}, G D I X_{t}, T R A D E_{t}\right)^{\prime}$. The test for cointegration is based on the rank of the matrix $\pi .^{13}$

The results of the cointegration test are presented in Table 6. In panels A, B and $\mathrm{C}$, we report the results for the full sample, low income and high income developing countries respectively. We report both trace statistics and max-eigenvalue statistics. ${ }^{14,15}$ As we can see from the table, the variables are not cointegrated for the full sample. However, for both low and high income developing countries there exists evidence of a cointegrating relationship between Theil's index, GDI, FDI and trade openness index. ${ }^{16}$

The normalized cointegrating coefficients suggest that FDI and trade openness have positive effects, and domestic investment has a negative effect on productivity differences among the low income developing countries. ${ }^{17}$ The $\chi^{2}$ test statistics

\footnotetext{
${ }^{12}$ Note that the Engle-Granger Cointegration Test procedure involves testing for stationarity of the error term in a hypothesized long-run relationship between two variables of interest. Johansen's procedure extends the concept and generalizes to the multivariate case.

${ }^{13}$ Note that bold face is used to denote a vector or matrix.

${ }^{14}$ For a discussion on these test statistics, see Enders (2004).

${ }^{15}$ We fit an equal lag length VAR to I, FDIX, GDIX and TRADE in levels for each group and use the system-wide SIC (alternatively, Akaike Information Criterion (AIC)) to determine the appropriate lag length. We then choose the selected lag length minus 1 to be the lag length of the differenced terms in equation (7).

${ }^{16}$ For low income developing countries, only trace statistics suggests that the variables are cointegrated at $5 \%$ significance level.

${ }^{17}$ The cointegrating equation with normalized coefficients for low income countries is: $I_{t}=$ -0.22 GDIX $_{t}+0.04 F D I X_{t}+0.03$ RRADE $_{t}$ and for high income developing countries is: $I_{t}=$ $-0.11 G D I X_{t}+0.15 F D I X_{t}-0.08 T R A D E_{t}+0.002 t$.
} 


\section{G.G. Das et al.}

Table 6. Johansen cointegration test for $I_{t}, G D I X_{t}, F D I X_{t}$ and $T R A D E_{t}$

Panel A: Full Sample of Countries

Trend and intercept specifications: linear deterministic trends in data; intercept and trend in cointegrating equation

Lag interval in first differences: No lags

Included observations: 31

\begin{tabular}{lccccc}
\hline $\begin{array}{l}\text { Null } \\
\text { Hypothesis }\end{array}$ & Eigenvalue & $\begin{array}{c}\text { Trace } \\
\text { Statistics }\end{array}$ & $\begin{array}{c}5 \% \text { critical } \\
\text { value }\end{array}$ & $\begin{array}{c}\text { Maximum } \\
\text { Eigenvalue } \\
\text { Statistics }\end{array}$ & $\begin{array}{c}5 \% \text { critical } \\
\text { value }\end{array}$ \\
\hline No CE & 0.33 & 25.97 & 47.21 & 12.54 & 27.07 \\
At most 1 CE & 0.23 & 13.43 & 29.68 & 8.28 & 20.97 \\
At most 2 CE & 0.14 & 5.15 & 15.41 & 4.79 & 14.07 \\
At most 3 CE & 0.01 & 0.36 & 3.76 & 0.36 & 3.76 \\
\hline
\end{tabular}

Panel B: Low Income Developing Countries

Trend and intercept specifications: linear deterministic trends in data; intercept

in cointegrating equation

Lag interval in first differences: No lags

Included observations: 30

\begin{tabular}{lccccc}
\hline $\begin{array}{l}\text { Null } \\
\text { Hypothesis }\end{array}$ & Eigenvalue & $\begin{array}{c}\text { Trace } \\
\text { Statistics }\end{array}$ & $\begin{array}{c}5 \% \text { critical } \\
\text { value }\end{array}$ & $\begin{array}{c}\text { Maximum } \\
\text { Eigenvalue } \\
\text { Statistics }\end{array}$ & $\begin{array}{c}5 \% \text { critical } \\
\text { value }\end{array}$ \\
\hline No CE & 0.55 & 51.00 & 47.21 & 24.10 & 27.07 \\
At most 1 CE & 0.39 & 26.90 & 29.68 & 14.64 & 20.97 \\
At most 2 CE & 0.33 & 12.26 & 15.41 & 11.83 & 14.07 \\
At most 3 CE & 0.01 & 0.43 & 3.76 & 0.43 & 3.76 \\
\hline
\end{tabular}

Normalized cointegrating coefficients: (standard errors are in parentheses)

1 Cointegrating Equation
$I_{t}$
1.00
$G D I X_{t}$
FDIX
$-0.04$
TRADE
0.22

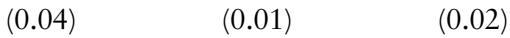
$-0.03$

$\chi^{2}$ test statistics for parameter restrictions: $\beta_{i}=0$ ( $p$-values are in parentheses)
3.14
6.05
0.44
(0.08)
(0.01)
$(0.51)$

Speed of adjustment parameters $\left(\chi^{2}\right.$ test statistics and associated $p$-values for parameter restrictions are in parentheses)
$-0.03$
$-1.33$
24.18
$-0.76$
$(0.10,0.75)$
$(2.52,0.11)$
$(4.97,0.03)$
$(0.09,0.76)$

Panel C: High Income Developing Countries

Trend and intercept specifications: linear deterministic trends in data; intercept and trend in cointegrating equation

Lag interval in first differences: 1 lag

Included observations: 31

\begin{tabular}{lccccc}
$\begin{array}{l}\text { Null } \\
\text { Hypothesis }\end{array}$ & Eigenvalue & $\begin{array}{c}\text { Trace } \\
\text { Statistics }\end{array}$ & $\begin{array}{c}5 \% \text { critical } \\
\text { value }\end{array}$ & $\begin{array}{c}\text { Maximum } \\
\text { Eigenvalue } \\
\text { Statistics }\end{array}$ & $\begin{array}{c}5 \% \text { critical } \\
\text { value }\end{array}$ \\
\hline No CE & 0.78 & 85.57 & 62.99 & 46.69 & 31.46 \\
At most 1 CE & 0.39 & 38.89 & 42.44 & 15.30 & 25.54 \\
At most 2 CE & 0.36 & 23.58 & 25.32 & 13.80 & 18.96 \\
At most 3 CE & 0.27 & 9.79 & 12.25 & 9.79 & 12.25 \\
\hline
\end{tabular}


Table 6. Continued

\begin{tabular}{|c|c|c|c|c|c|}
\hline $\begin{array}{l}\text { Null } \\
\text { Hypothesis }\end{array}$ & Eigenvalue & $\begin{array}{c}\text { Trace } \\
\text { Statistics }\end{array}$ & $\begin{array}{l}5 \% \text { critical } \\
\text { value }\end{array}$ & $\begin{array}{c}\text { Maximum } \\
\text { Eigenvalue } \\
\text { Statistics }\end{array}$ & $\begin{array}{l}5 \% \text { critical } \\
\text { value }\end{array}$ \\
\hline \multicolumn{6}{|c|}{ Normalized cointegrating coefficients: (standard errors are in parentheses) } \\
\hline$G S_{t}$ & GDIX $_{t}$ & FDIX $_{t}$ & $T R A D E_{t}$ & Trend & \\
\hline 1.00 & $\begin{array}{c}0.11 \\
(0.06)\end{array}$ & $\begin{array}{l}-0.15 \\
(0.02)\end{array}$ & $\begin{array}{c}0.08 \\
(0.09)\end{array}$ & $\begin{array}{l}-0.002 \\
(0.005)\end{array}$ & \\
\hline \multicolumn{6}{|c|}{$\chi^{2}$ test statistics for parameter restrictions: $\beta_{i}=0$} \\
\hline & $\begin{array}{l}1.69 \\
(0.19)\end{array}$ & $\begin{array}{l}23.60 \\
(0.00)\end{array}$ & $\begin{array}{c}0.65 \\
(0.42)\end{array}$ & 12.30 & \\
\hline \multicolumn{6}{|c|}{$\begin{array}{l}\text { Speed of adjustment parameters ( } \chi^{2} \text { test statistics and associated } p \text {-values for parameter } \\
\text { restrictions are in parentheses) }\end{array}$} \\
\hline $\begin{array}{l}-0.16 \\
(23.38,0.00)\end{array}$ & $\begin{array}{c}0.62 \\
(3.79,0.05)\end{array}$ & $\begin{array}{c}2.80 \\
(5.26,0.02)\end{array}$ & $\begin{array}{c}1.08 \\
(12.63,0.00)\end{array}$ & & \\
\hline
\end{tabular}

(see Table 6, Panel B) indicate that only the coefficients for GDIX and FDIX are statistically significant at least at the $10 \%$ level. The speed of adjustment coefficient of the productivity difference equation has the correct sign and it indicates that any deviation from the long-run equilibrium will adjust, although slowly (indicated by small absolute value of the coefficient). However, the coefficient is statistically insignificant as shown by the value of $\chi^{2}$ test statistics and associated $p$-value. While the speed of adjustment coefficients for GDI and trade are not statistically significant, it is significant for FDI and has the wrong sign. For high income developing countries, however, FDI has a significant positive impact on productivity differences and GDI and trade openness seem to have negative but statistically insignificant effects. ${ }^{18}$ All the speed of adjustment coefficients, except for FDI, have the correct signs and they are all statistically significant. These results imply that none of the variables is exogenous and they respond to any deviation from the long-run relationship described by the cointegrating equation.

Thus, there is no evidence of any systematic effect of GDI, FDI and trade on the evolution of the productivity difference measure in the long-run for the full sample of countries examined in this study. However, it may not always be true when we categorize the countries by income groups. In particular, our analysis suggests that FDI increases productivity differences in the long-run among countries in two groups: 'low income developing countries' and 'high income developing countries.' Furthermore, GDI appears to be important for reducing productivity gaps among low income developing countries in the long-run. The results also indicate that any deviation of the productivity difference measure from its long-run path determined by the above relationships for both these two groups of countries is transitory in nature.

\footnotetext{
${ }^{18}$ It is difficult to interpret the estimated coefficients. Roughly, it suggests that an average (weighted) $1 \%$ increase in FDI per worker increases Theil's index by 0.15 among the high income developing countries.
} 


\subsubsection{Granger Causality Test}

We conduct Granger Causality Tests to further investigate the relationships among I, GDIX, FDIX and TRADE for the groups of countries for which we did not have any evidence of cointegration. We use the multivariate generalization of the Granger Causality Test, which is also called the 'block causality' test. A likelihood ratio test is used to test the cross equation restrictions on the lags of the variables of interest. Note that the test statistics are estimated from a VAR model of the four variables in their stationary forms. ${ }^{19}$ The objective of this exercise is to determine whether lags of one variable Granger cause any other variable in the system. ${ }^{20}$ Granger causality thus implies temporal causality: whether movements in one variable systematically precede the movements in another variable. Since a statistically significant speed of adjustment coefficient in a system of equations in which cointegrating relationship is present, is interpreted as indicating long-run Granger causality, evidence of Granger causality in the absence of cointegrating relationship can be thought of as indicating short-run Granger causality.

The results are reported in Table 7. For the full sample there is no evidence of Granger causality among the variables. Since most lag selection criteria choose 0 to be the best lag for VAR of the first differences of the variables, the Granger causality test is trivial and, therefore, the results are not reported. For middle income developing countries, we find that GDI Granger-causes trade, which, in turn, Granger-causes FDI. Estimated VAR results (which are not reported in the paper to save space) indicate that an increase in GDI leads to a decline in the growth of trade, whereas an increase in the growth of trade accelerates the growth of FDI. Thus, increasing trade seems to be important for attracting foreign investment in middle income developing countries. For developed countries, productivity differences and FDI Granger-cause trade. A reduction in productivity gap and higher FDI growth seem to increase trade among developed countries.

\subsection{Discussion of the Results}

The lack of a clear pattern in the short-run with some evidence of long-run divergence in labor productivity among the countries in our full sample is not surprising, particularly when it includes both developed and developing countries with wide ranging growth experiences and policy experiments. As expected, however, we observe clearer patterns when we divide the countries into various income groups. In contrast to the narrowing differences among the middle income developing and the developed countries, labor productivity differences have widened, particularly in the 1990s, among low income and high income developing countries.

Note that the group of low income countries includes India, Malawi, Pakistan and Sri Lanka, which have achieved high growth during the 1990s, as well as some countries of sub-Saharan Africa and Latin America that have experienced little

\footnotetext{
${ }^{19}$ As suggested by Fomby (1998), for a group we first fit a equal lag length VAR to the stationary forms of the variables, and determine the appropriate lag length using system-wide SIC and then conduct block causality tests.

${ }^{20}$ For a discussion, see Enders (2004, 283-4).
} 
Table 7. Pairwise Granger causality test

Panel A: Middle Income Countries

Lag length of the differenced variables $=1$

Observations $=30$

\begin{tabular}{|c|c|c|c|c|c|}
\hline & & \multicolumn{4}{|c|}{ Dependent variables } \\
\hline & & $I_{t}$ & $G D I X_{t}$ & $\Delta F D I X_{t}$ & $\triangle T R A D E_{t}$ \\
\hline \multirow[t]{5}{*}{$\chi^{2}$ test statistics for exclusion of: } & $I_{t}$ & & $\begin{array}{c}2.45 \\
(0.12)\end{array}$ & $\begin{array}{c}0.17 \\
(0.68)\end{array}$ & $\begin{array}{c}1.12 \\
(0.29)\end{array}$ \\
\hline & GDIX $_{t}$ & $\begin{array}{c}0.00 \\
(0.98)\end{array}$ & & $\begin{array}{c}0.31 \\
(0.58)\end{array}$ & $\begin{array}{c}5.26 \\
(0.02)\end{array}$ \\
\hline & $\Delta F D I X_{t}$ & $\begin{array}{c}0.02 \\
(0.89)\end{array}$ & $\begin{array}{c}0.39 \\
(0.53)\end{array}$ & & $\begin{array}{c}0.13 \\
(0.72)\end{array}$ \\
\hline & $\triangle T R A D E_{t}$ & $\begin{array}{c}0.60 \\
(0.44)\end{array}$ & $\begin{array}{l}1.65 \\
(0.20)\end{array}$ & $\begin{array}{l}5.67 \\
(0.02)\end{array}$ & \\
\hline & All & $\begin{array}{c}0.63 \\
(0.89)\end{array}$ & $\begin{array}{l}3.90 \\
(0.27)\end{array}$ & $\begin{array}{c}6.32 \\
(0.097)\end{array}$ & $\begin{array}{l}7.09 \\
(0.07)\end{array}$ \\
\hline
\end{tabular}

Panel B: Developed Countries

Lag length of the differenced variables $=1$

Observations $=30$

\begin{tabular}{|c|c|c|c|c|c|}
\hline & \multicolumn{4}{|c|}{ Dependent variables } \\
\hline & & $I_{t}$ & $G D I X_{t}$ & $\Delta F D I X_{t}$ & $\triangle T R A D E_{t}$ \\
\hline \multirow[t]{5}{*}{$\chi^{2}$ test statistics for exclusion of: } & $I_{t}$ & & 0.97 & 0.05 & \multirow{5}{*}{$\begin{array}{c}4.12 \\
(0.04) \\
1.55 \\
(0.21) \\
3.37 \\
(0.07)\end{array}$} \\
\hline & $\Delta G D I X_{t}$ & 0.02 & & 0.81 & \\
\hline & $\Delta F D I X_{t}$ & $\begin{array}{c}0.54 \\
(0.46)\end{array}$ & $\begin{array}{c}0.15 \\
(0.69)\end{array}$ & & \\
\hline & $\triangle T R A D E_{t}$ & $\begin{array}{c}0.05 \\
(0.83)\end{array}$ & $\begin{array}{c}0.01 \\
(0.94)\end{array}$ & $\begin{array}{c}0.02 \\
(0.88)\end{array}$ & \\
\hline & All & $\begin{array}{l}1.35 \\
(0.72)\end{array}$ & $\begin{array}{l}1.35 \\
(0.72)\end{array}$ & $\begin{array}{l}1.93 \\
(0.59)\end{array}$ & \\
\hline
\end{tabular}

growth. The result that FDI increases productivity differences while GDI reduces them among low income developing countries seems to suggest that the impact of FDI dominates the impact of GDI. ${ }^{21}$ The role of FDI and trade as conduits of technology transfer, as discussed in Saggi (2002), may have been crucial in this regard. Better technology and trade liberalization - which leads to higher trade along with other market oriented reforms may have enhanced efficiency and thus labor productivity in some countries while the rest in this group have stagnated. This explanation accords well with the findings of a recent cross-country study by Ferreira et al. (2008). They show that although countries have converged in factor accumulation they have diverged in terms of total factor productivity (TFP). Growth of TFP - broadly defined to encompass both technical and allocative efficiency - may stem from a whole host of factors including new technology adoption, market oriented policy reforms, trade openness etc. Some of the low income countries mentioned above not only have received larger flows of FDI

${ }^{21}$ Note that trade also has a positive but statistically insignificant effect on productivity difference. 
along with advanced technology but also have carried out market oriented and trade policy reforms.

The group of high income developing countries includes Cyprus, Hong Kong, Korea, Malaysia and Singapore, which have achieved economic miracles, as well as countries that have performed poorly, such as Argentina and Gabon, during the sample period. The flow of FDI has been continuously rising to these countries as a group but there has been substantial short-run variation among them. Furthermore, while trade has increased by several times in Hong Kong, Korea, Malaysia and Singapore since the late 1980s as a result of liberal trade policies, it has either stagnated or declined in Barbados and Gabon. FDI has followed a similar pattern. As Balasubramanyam et al. (1996) and Nair-Reichert \& Weinhold (2001) show, the positive effects of FDI are stronger in countries with more open trade. Thus, FDI may have increased labor productivity in fast growing countries with more liberal trade regimes, widening the difference with the rest in the group.

The short-run relationship between productivity difference measure, GDI, FDI and trade in middle income developing and developed countries presents a different picture and warrants different explanations. Both FDI and trade have increased among the middle income developing countries while GDI sharply declined since the mid-1970s and has stabilized since mid-1980s. This group includes high performers such as Thailand, the Dominican Republic, Indonesia and Turkey, as well as countries with disastrous growth performance, such as Bolivia and Venezuela. From our Granger causality test results it is not clear why an increase in domestic capital accumulation slows down the growth of trade. It may be reflective of the fact that some of these countries (Venezuela is an example) are pursuing inwardoriented policies that involve large domestic investment with less international trade. That increased trade attracts FDI is consistent with the literature discussed above. However, the convergence in labor productivity across these countries requires further investigation.

As for the developed counties, it is conceivable that there has been convergence in labor productivity. However, it is interesting that a reduction in productivity differences leads to an increase in trade in these countries. In general, the current wave of globalization with more and more countries around the world opening up their borders has increased the value and volume of trade. Other developments include international disintegration of the production process and trade in services, facilitated by technology. ${ }^{22,23}$ These developments have contributed to international specialization and an increase in productivity in most developed countries. It is likely that labor productivity differences have decreased as a result. Furthermore, this spatial disintegration of production across countries has increased FDI flows among developed countries, which in turn may have increased trade, mostly at the intermediate level.

\footnotetext{
${ }^{22}$ The 'international disintegration of the production process' refers to the process in which manufacturing or services activities at intermediate stages are done in different countries and then assembled in one country to deliver the final product. This phenomenon has been discussed by Bhagwati \& Dehejia (1994), Krugman (1996) and Leamer (1996). For an early survey, see Feenstra (1998).

${ }^{23}$ For a detailed account of international trade in services, see Mattoo et al. (2008).
} 
Most of the above explanations of our empirical results are suggestive, at best, and they require further empirical investigation, which is outside the scope of this current paper.

\section{Concluding Remarks}

Using annual data for 92 countries around the world, this paper calculates Theil's entropy index to measure the extent of productivity differences across countries for the period from 1970 to 2003. While there is evidence of increasing differences in productivity across these countries, we observe different patterns when we group the countries by income levels. Theil's index exhibits significant negative trends for middle income and developed countries, whereas the differences seem to be increasing among the low income and high income developing countries. This paper also investigates how domestic and foreign direct investment and trade affect the behavior of the productivity difference measure using multivariate time series techniques such as a cointegration test and granger causality test. For the entire sample we find no evidence of a short-run or long-run causal relationship. However, for low and high income developing countries the investment and trade variables are cointegrated with Theil's index, indicating the presence of a long-run causal relationship. For both these groups, FDI appears to increase differences in productivity in the long-run. Domestic investment, on the other hand, reduces productivity differences among low income countries. Furthermore, Granger causality test results indicate that while an increase in GDI leads to a reduction in the growth of trade, a higher growth of trade is important for attracting FDI to middle income countries. In addition, a reduction in productivity differences and a higher level of FDI growth are important for growth of trade in developed countries.

This is a macro-level study that does not address many important specific micro-level issues. In addition to the shortcomings associated with the data, this paper does not address the issue of inequality in productivity within a country. Whether GDI and FDI are complements or substitutes, if FDI is market-seeking or efficiency seeking, how these motives affect productivity, and whether other country-specific factors will systematically affect productivity difference, are some of the issues that have not been addressed in this paper. Because the main focus of this paper is to measure the extent and evolution productivity differences across countries, these issues are not entirely within the scope of this study. But future research will try to address some of these issues.

\section{Acknowledgements}

An earlier version of this paper, under the title 'Foreign Direct Investment and Inequality in Productivity Across Countries' was presented at the 50th Annual North American Meetings of the Regional Science Association International in Philadelphia, November 2003. The authors would like to thank Maria Abreu, Sunwoong Kim and an anonymous referee for their comments and suggestions. We also thank David Matthews for his excellent research assistance. The authors are solely responsible for any remaining error. 


\section{References}

Balasubramanyam, V. N., Salishu, M. \& Sapsford, D. (1996) Foreign direct investment and growth in EP and IS countries, Economic Journal, 106, pp. 92-105.

Basu, P., Chakraborty, C. \& Reagle, D. (2003) Liberalization, FDI, and growth in developing countries: a panel cointegration approach, Economic Enquiry, 41(3), pp. 510-516.

Bhagwati, J. \& Dehejia, V.H. (1994) Freer trade and wages of the unskilled - is Marx striking again? in: J. Bhagwati and M.H. Kosters (Eds) Trade and Wages: Leveling Wages Down? pp. 36-75 (Washington, DC: The American Enterprise Institute Press).

Bhatta, S.D. (2002) Has the increase in world-wide openness to trade worsened global income inequality? Papers in Regional Science, 81(2), pp. 177-196.

Borensztein, E., De Gregorio, J. \& Lee, J.-W. (1998) How does foreign direct investment affect economic growth? Journal of International Economics, 45, pp. 115-135.

Center for International Comparisons (CIC), Penn World Tables (http://pwt.econ.upenn.edu/) (Philadelphia, PA: University of Pennsylvania).

Choe, J. (2003) Do foreign direct investment and gross domestic investment promote economic growth? Review of Development Economics, 7(1), pp. 44-57.

Cowell, F.A. (1995) Measuring Inequality (London: Prentice Hall/Harvester Wheatsheaf).

Cuadrado, J.R., Dehesa, G. \& Precedo, A. (1993) Regional imbalances and government compensatory financial flows: the case study of Spain, in: A. Giovannini (Ed.) Finance and Development: Issues and Experience (Cambridge: Cambridge University Press).

Das, S.K. \& Barua, A. (1996) Regional inequalities, economic growth and liberalisation: a study of the Indian economy, The Journal of Development Studies, 32(3), pp. 364-390.

de Mello, L.R. (1999) Foreign direct investment-led growth: evidence from time series and panel data, Oxford Economic Papers, 51, pp. 133-151.

Enders, W. (2004) Applied Econometric Time Series, 2nd ed. (New York: Wiley).

Feenstra, R.C. (1998) Integration of trade and disintegration of production in the global economy, Journal of Economic Perspectives, 12(4), pp. 31-50.

Ferreira, P.C., Pessoa, S.A. \& Veloso, F.A. (2008) The evolution of international output differences (1970-2000): from factors to productivity, The B.E. Journal of Macroeconomics, 8(1) (Topics).

Fomby, T.B. (1998) Learning by doing: teaching econometrics students how to model multivariate time series data. Unpublished manuscript, Department of Economics, Southern Methodist University.

Krugman, P. (1996) Does third world growth hurt first world prosperity? Harvard Business Review, 72, pp. $113-121$.

Leamer, E.E. (1996) In search of Stolper-Samuelson effects on U.S. wages, NBER Working Paper no. 5427.

Mankiw, N.G. (2004) Principles of Economics, 3rd ed. (Mason, OH: Thomson South-Western).

Mattoo, A., Stern, R.M. \& Zanini, G. (2008) A Handbook of International Trade in Services (Oxford: Oxford University Press).

Nair-Reichert, U. \& Weinhold, D. (2001) Causality tests for cross country panels: new look at FDI and economic growth in developing countries, Oxford Bulletin of Economics and Statistics, 63, pp. 153-171.

Phillips, P. \& Perron, P. (1988) Testing for a unit root in time series regression, Biometrica, 75, pp. $335-346$.

Ram, R. (1989) Level of development and income inequality: an extension of Kuznets-hypothesis to the world economy, Kyklos, 42(1), pp. 73-88.

Saggi, K. (2002) Trade, foreign direct investment and international technology transfer: a survey, World Bank Research Observer, 17, pp. 191-235.

Theil, H. (1967) Economics and Information Theory (Amsterdam: North-Holland).

\section{Appendix A. Gini Coefficient}

The Gini coefficient is the most widely used aggregate measure of income inequality among the population in an economy. Since this paper examines inequality in labor productivity among countries, it uses a spatial Gini, GS, that is based on 
spatial units. ${ }^{24}$ The underlying assumption is that every worker in a country has the same labor productivity, which is defined as real gross domestic product per worker in that country. $G S_{t}$, the spatial Gini of labor productivity across countries in period $t$, is derived by using a trapezoidal approximation for the area under the Lorenz curve as follows:

$$
G S_{t}=1-\sum_{i=0}^{n-1}\left(\frac{Y_{i, t}^{S}+Y_{i+1, t}}{Y_{t}}\right)\left(\frac{L_{i+1, t}^{S}-L_{i, t}^{S}}{L_{t}}\right)
$$

where $n$ is the number of countries in the sample, $Y_{i, t}$ is the real GDP in country $i$ in period $t$ and $Y_{t}=\sum_{i=1}^{n} Y_{i, t} . Y_{i, t}^{S}$ is the aggregate real GDP of all countries with real GDP per worker (RGDPPW) less than RGDPPW in country $i$ period $t$. $L_{t}$ is the total number of workers in the sample countries. $L_{i, t}^{S}$ is the total number of workers in countries with $R G D P P W \leq R G D P P W_{i}$ in period $t$. We take $L_{0}=Y_{0}=0$. Note that $G S_{t}$ can take values only between 0 and 1,0 indicating complete equality and 1 indicating extreme inequality. ${ }^{25}$

\section{Appendix B. List of Countries}

\section{Full Sample (92 countries)}

Angola, Argentina, Australia, Austria, Barbados, Benin, Bolivia, Brazil, Burkina Faso, Cameroon, Canada, Central African Republic, Chad, Chile, Colombia, Congo, Costa Rica, Cote d'Ivoire, Cyprus, Democratic Republic of Congo, Denmark, Dominican Republic, Ecuador, Egypt, El Salvador, Ethiopia, Fiji, Finland, France, Gabon, Gambia, Ghana, Greece, Guatemala, Guyana, Haiti, Honduras, Hong Kong, Iceland, India, Indonesia, Iran, Ireland, Israel, Italy, Jamaica, Japan, Kenya, Korea, Madagascar, Malawi, Malaysia, Mauritania, Mauritius, Mexico, Morocco, Mozambique, Netherlands, New Zealand, Nicaragua, Niger, Nigeria, Norway, Pakistan, Panama, Papua New Guinea, Paraguay, Peru, Philippines, Portugal, Rwanda, Senegal, Seychelles, Sierra Leone, Singapore, South Africa, Spain, Sri Lanka, Sweden, Tanzania, Thailand, Togo, Trinidad and Tobago, Tunisia, Turkey, Uganda, UK, Uruguay, USA, Venezuela, Zambia, Zimbabwe.

\section{Developed Countries (20 countries)}

Australia, Austria, Canada, Denmark, France, Finland, Greece, Iceland, Ireland, Israel, Italy, Japan, Netherlands, New Zealand, Norway, Portugal, Spain, Sweden, United Kingdom, United States of America.

\footnotetext{
${ }^{24}$ For a discussion, see Cowell (1995).

${ }^{25}$ One major drawback of this measure is that because it is a measure of aggregate inequality, it fails to adequately take into account certain changes in the underlying distribution of productivity. For a detailed discussion, see Bhatta (2002).
} 
High Income Developing Countries (13 countries)

Countries with per capita GDP above \$4,000 in 1995

Argentina, Barbados, Brazil, Chile, Cyprus, Gabon, Hong Kong, Korea, Malaysia, Seychelles, Singapore, Trinidad and Tobago, Uruguay.

Middle Income Developing Countries (26 countries)

Countries with per capita GDP between \$ 800 and \$4,000 in 1995

Bolivia, Colombia, Congo, Costa Rica, Dominican Republic, Ecuador, Egypt, El Salvador, Fiji, Guatemala, Indonesia, Iran, Jamaica, Mauritius, Mexico, Morocco, Panama, Papua New Guinea, Paraguay, Peru, Philippines, South Africa, Thailand, Tunisia, Turkey, Venezuela.

Low Income Developing Countries (33 countries)

Countries with per capita GDP below $\$ 800$ in 1995

Angola, Benin, Burkina Faso, Cameroon, Central African Republic, Chad, Cote d'Ivoire, Democratic Republic of Congo, Ethiopia, Gambia, Guyana, Haiti, Honduras, India, Kenya, Madagascar, Malawi, Mauritania, Mozambique, Nicaragua, Niger, Nigeria, Pakistan, Rwanda, Senegal, Sierra Leone, Sri Lanka, Tanzania, Togo, Uganda, Zambia, Zimbabwe. 
Copyright of International Economic Journal is the property of Routledge and its content may not be copied or emailed to multiple sites or posted to a listserv without the copyright holder's express written permission. However, users may print, download, or email articles for individual use. 